\title{
Wpływ modyfikacji techniki fakoemulsyfikacji na oczekiwane parametry pooperacyjne
}

\author{
Modified technique of phacoemulsification and its impact on expected postoperative parameters
}

\author{
Magdalena Skorek, Piotr Jurowski \\ Klinika Okulistyki i Rehabilitacji Wzrokowej, Uniwersytet Medyczny w Łodzi \\ Kierownik: prof. dr hab. n. med. Piotr Jurowski
}

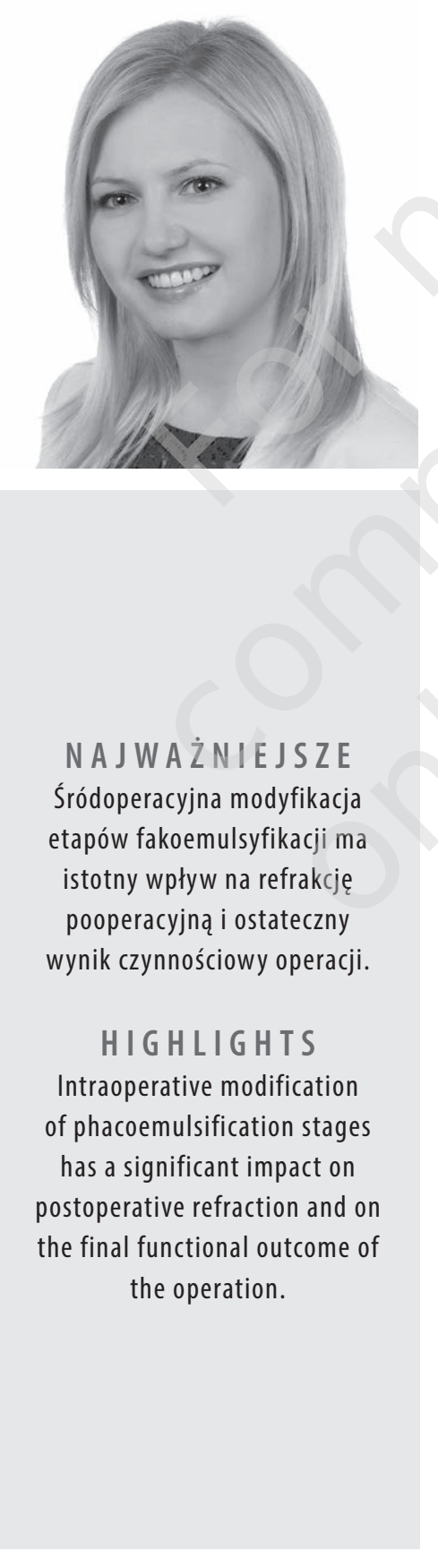

\section{STRESZCZENIE}

Fakoemulsyfikacja to powszechna procedura chirurgiczna, wykonywana na każdym oddziale okulistycznym. Dobra pooperacyjna ostrość wzroku jest pochodną wielu czynników przed-, śród-i pooperacyjnych, w tym prawidłowego pomiaru morfometrycznego gałki ocznej i kalkulacji mocy sztucznej soczewki z zastosowaniem odpowiedniej formuły obliczeniowej. Przystępując do operacji, okulista powinien dysponować szeroką wiedzą o potencjalnym wpływie modyfikacji techniki operacyjnej na pooperacyjną ostrość wzroku, ponieważ wykonanie dodatkowych manipulacji śródoperacyjnych może się wiązać z nieoczekiwaną pooperacyjną ametropią i z koniecznością korekty wartości refrakcyjnej wszczepianej soczewki wewnątrzgałkowej.

Słowa kluczowe: fakoemulsyfikacja, modyfikacje techniki fakoemulsyfikacji, formuły obliczeniowe soczewek wewnątrzgałkowych, astygmatyzm pooperacyjny

\section{ABSTRACT}

Phacoemulsification is a common surgical procedure performed in every ophthalmology department. Good postoperative visual acuity is the result of many pre-, intra and postoperative components, including correct morphometric measurement of the eyeball and calculation of the artificial lens power using an appropriate calculation formula. The ophthalmologist should have extensive knowledge of the potential impact of surgical technique modifications on the postoperative visual acuity, as performing additional intraoperative manipulations may be associated with unexpected postoperative ametropia and need to correct the refractive value of the implanted intraocular lens.

Key words: phacoemulsification, modifications of phacoemulsification, intraocular lens calculation formulas, postoperative astigmatism 


\section{WSTĘP}

Obserwowany obecnie wzrost średniej długości życia człowieka ma naturalny wpływ na zmiany w codziennym funkcjonowaniu, w tym na potrzebę utrzymania dobrej ostrości wzroku oraz całkowitej rezygnacji z okularów. Procedura fakoemulsyfikacji zaćmy, jak również usunięcie przeziernej soczewki, traktowane są obecnie jako procedury refrakcyjne.

W ciągu ostatnich dekad zwraca uwagę coraz bardziej restrykcyjne podejście do planowanej i uzyskiwanej refrakcji pooperacyjnej. W latach 80 . XX w. moc refrakcyjną wszczepianej soczewki określano jako wynik refrakcji pacjenta sprzed usunięcia zaćmy, do którego dodawano stałą wartość +19,0 D. W latach 90. za dobry wynik pooperacyjny uważano refrakcję pooperacyjną na poziomie $\pm 1,00 \mathrm{D}$. W 2006 r. Gale i wsp. wykazali, że wzorcowym standardem jest refrakcja pooperacyjna mieszcząca się w zakresie $\pm 0,50$ D i została ona zanotowana w $55 \%$ przypadków. Z kolei zakres $\pm 1,00$ D obserwowany był w $85 \%$ operowanych oczu [1]. Dla porównania obecnie zakres ametropii $\pm 0,50$ D uzyskiwany jest w ponad 70\% przypadków, a zakres $\pm 1,00 \mathrm{D}$ w ponad $90 \%$ operowanych oczu.

Otrzymanie tak dobrych wyników jest możliwe dzięki staranności i dokładności wykonania pomiarów morfometrycznych gałki ocznej z zastosowaniem coraz nowszych metod obliczeniowych, w połączeniu z zaawansowanymi technikami chirurgicznymi.

Bardzo istotnym aspektem przed przeprowadzeniem operacji jest jej indywidualne zaplanowanie dla danego pacjenta, z wyliczeniem mocy refrakcyjnej soczewki wewnątrzgałkowej tak, aby pooperacyjna ostrość wzroku była jak najbardziej zbliżona do zaplanowanej.

Jak powszechnie wiadomo, do wyliczenia mocy implantu soczewkowego niezbędnych jest kilka parametrów morfometrycznych gałki ocznej, w tym (ryc. 1):

1. Keratometria - pomiar krzywizny rogówki (K, keratometry).

2. Biometria - pomiar długości osiowej gałki ocznej (AL, axial length). Pomiar uzyskujemy z zastosowaniem metody ultrasonograficznej - przyjmuje się, że punkt końcowy pomiaru znajduje się w błonie granicznej wewnętrznej siatkówki - lub metody optycznej, w której za punkt końcowy pomiaru przyjmuje się nabłonek barwnikowy siatkówki. Biorąc powyższe pod uwagę, można przyjąć, że biometria optyczna określa refrakcyjną długość osiową, a biometria ultrasonograficzna - anatomiczną długość osiową gałki ocznej. Dokładność pomiaru długości osiowej gałki ocznej jest wyjątkowo istotna w określeniu mocy refrakcyjnej sztucznej soczewki. Wiadomo, że błąd pomiaru o $1 \mathrm{~mm}$ będzie skutkował zmianą refrakcji aż o ok. 3,0 D.
3. Dodatkowe pomiary stosowane w niektórych formułach obliczeniowych, takie jak pomiar głębokości komory przedniej (ACD, anterior chamber depth) oraz wynikająca z tej wartości tzw. efektywna pozycja soczewki (ELP, effective lens position).

Obecnie dysponujemy czterema generacjami formuł obliczeniowych (tab. 1). Generacja I bazowała tylko na matematycznych obliczeniach opartych na sztucznym schemacie oka. Generacja II uzupełniała powyższe dane o wyniki pooperacyjne. Chociaż obie formuły nie znajdują już zastosowania w praktyce klinicznej, to stanowiły podstawę opracowania formuły III i IV generacji $[2,3]$.

\section{RYCINA 1}

\section{Parametry morfometryczne gałki ocznej.}

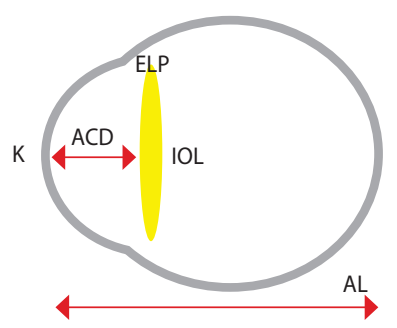

ACD (anterior chamber depth) - głębokość komory przedniej; AL (axial length) długość osiowa; ELP (effective lens position) - efektywna pozycja soczewki; IOL (intraocular lens) - soczewka wewnątrzgałkowa; K (keratometry) keratometria

\section{TABELA $(1$}

\begin{tabular}{c|c|c|c}
\multicolumn{4}{c}{ Zestawienie formuł obliczeniowych. } \\
I generacja & II generacja & III generacja & IV generacja \\
\hline SRK & SRK II & SRK/T & Holladay 2 \\
\hline $\begin{array}{c}\text { Binkhorst } \\
\text { formula }\end{array}$ & & Hoffer Q & Haigis \\
\hline & & Holladay & Olsen
\end{tabular}

Ostatecznie III i IV generację formuł oparto na bazie matematycznych obliczeń mocy refrakcyjnej wszczepu soczewkowego zmodyfikowanych o pozyskane wyniki pooperacyjne. Na podstawie wielu przeprowadzonych na przestrzeni lat badań porównujących formuły obliczeniowe wykazano, że wyniki obliczeń formuł I i II generacji znacznie odbiegają od wyników formuł III i IV generacji i powinno się całkowicie zaniechać stosowania tych pierwszych. Zwrócono również uwagę na fakt, że przy różnych długościach gałek ocznych zastosowane formuły III i IV generacji mogą wskazywać odmienne wyniki. Wniosek z licznych opracowań na ten temat wskazuje, że wybór formuły obliczeniowej powinien być uzależniony od długości gałki ocznej pacjenta (tab. 2). 
Zastosowanie formuł obliczeniowych w zależności od długości osiowej gałki ocznej.

\begin{tabular}{c|c} 
AL - długość gałki ocznej & Formuła obliczeniowa \\
\hline$<20 \mathrm{~mm}$ & Haigis/Holladay 2 \\
\hline $20-22 \mathrm{~mm}$ & Haigis/Holladay 2/ewentualnie Hoffer Q \\
\hline $22-24,5 \mathrm{~mm}$ & Każda formuła III i IV generacji \\
\hline $24,5-26 \mathrm{~mm}$ & Każda formuła III i IV generacji \\
\hline$>26 \mathrm{~mm}$ & SRKT/T/ewentualnie Holladay 1
\end{tabular}

Jedną z najnowszych metod obliczeniowych jest kalkulator Barretta $[4,5]$, który posiada trzy typy formuł obliczeniowych (dostępnych również w wersji online):

1. formułę Universal II - stosowaną do obliczania mocy refrakcyjnej soczewek sferycznych (http://calc.apacrs. org/barrett_universal2105)

2. formułę Barretta - stosowaną w przypadku kalkulacji soczewek torycznych (https://calc.apacrs.org/toric_calculator20/Toric\%20Calculator.aspx), występującą także w wersji polskiej (https://www.myalcon-toriccalc. com/\#/calculator) oraz

3. formułę True-K - służącą do obliczania mocy refrakcyjnej sztucznej soczewki u pacjentów, u których wykonano wcześniej zabiegi z zakresu chirurgii refrakcyjnej (http://calc.apacrs.org/Barrett_True_K_Universal_2105).

Jak się uważa, dokładność kalkulatora Barretta jest oparta na rozbudowanej liczbie analizowanych parametrów. Oprócz pomiaru długości osiowej gałki ocznej i keratometrii w obliczeniach kalkulator Barretta uwzględnia również efektywną pozycję soczewki i krzywiznę tylnej powierzchni rogówki (wyliczone pośrednio na podstawie pomiaru głębokości komory przedniej gałki ocznej) oraz astygmatyzm indukowany chirurgicznie (SIA, surgically induced astigmatism). Włączenie SIA do kalkulacji mocy refrakcyjnej sztucznej soczewki wewnątrzgałkowej jest nowatorskim podejściem wynikającym z faktu, że manipulacje śródoperacyjne mają wpływ na wartość astygmatyzmu indukowanego chirurgicznie, a więc i ostatecznie na wynik refrakcji pooperacyjnej.

Do najistotniejszych czynników wpływających na wartość astygmatyzmu indukowanego chirurgicznie należą: zaplanowana szerokość i lokalizacja cięcia głównego, lokalizacja i szerokość paracentez oraz zastosowana technika operacyjna.

\section{WPŁYW MODYFIKACJI TECHNIKI OPERACYJNEJ NA REFRAKCJĘ POOPERACYJNĄ}

Jedną z najczęściej wykonywanych modyfikacji jest poszerzenie głównego cięcia rogówkowego. Powodem takiego postępowania mogą być trudności we wprowadzeniu tipa fakoemulsyfikatora, brak swobody poruszania tipem aspiracyjnym podczas usuwania kory soczewki czy trudności we wszczepieniu implantu soczewkowego. Ta z pozoru niewielka zmiana może w znacznym stopniu wpłynąć na zaplanowaną refrakcję pooperacyjną [6].

Wspomniana modyfikacja wielkości cięcia rogówki ma szczególnie istotne znaczenie z punktu widzenia wielkości i osi astygmatyzmu rogówkowego. W sytuacji gdy gałka oczna wykazuje cechy astygmatyzmu zgodnego z regułą, czyli oś stromej krzywizny rogówki znajduje się w okolicy $90^{\circ}$, poszerzenie cięcia głównego wykonanego właśnie w tym obszarze spowoduje spłaszczenie krzywizny rogówki i jednocześnie zmniejszenie wartości cylindra.

Powyższą sytuację przedstawiono z zastosowaniem systemu wspomagania chirurga Verion (ryc. 2 i 3). U pacjenta $\mathrm{z}$ astygmatyzmem przedoperacyjnym o wartości 2,57 Dcyl w osi stromej (oś południka płaskiego wynosi $165^{\circ}$ ) zaplanowano dwa rodzaje szerokości cięcia głównego, oba w pobliżu osi stromej (cięcie główne na godzinie 12). W pierwszym planie operacyjnym ukazanym na rycinie 2 zaplanowano cięcie $2,4 \mathrm{~mm}$ wykonane w osi $90^{\circ}$. W tym przypadku oczekiwany wynik pooperacyjny wyniesie 1,79 Dcyl, a więc wartość astygmatyzmu zmniejszy się o 0,8 Dcyl. W przypadku poszerzenia cięcia głównego do $3,2 \mathrm{~mm}$ astygmatyzm pooperacyjny wyniesie 1,61 Dcyl i będzie mniejszy od astygmatyzmu przedoperacyjnego aż o 0,96 Dcyl.

Analiza powyższego przypadku pokazuje, że przy wykonaniu szerszego cięcia w obszarze, w którym znajduje się oś stroma astygmatyzmu, dochodzi do znaczniejszego spłaszczenia rogówki i większej zmiany wartości astygmatyzmu rogówkowego (ryc. 3). 


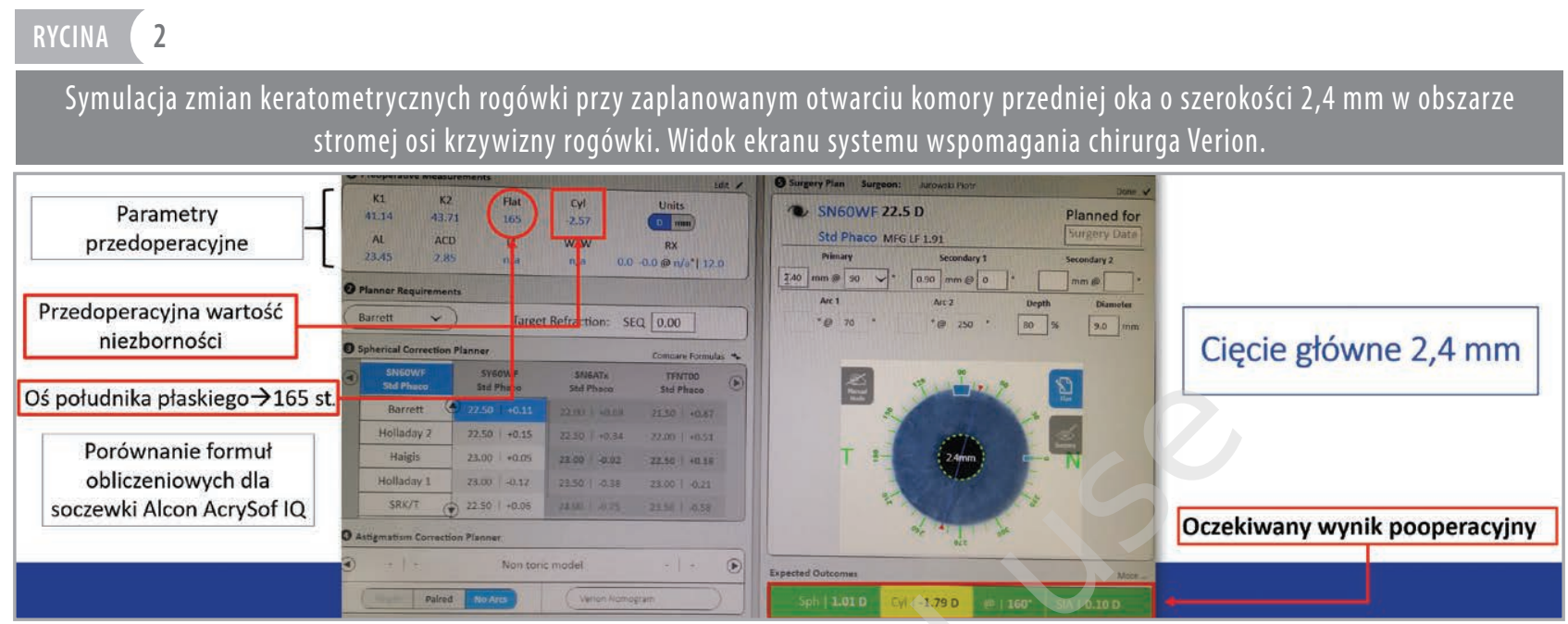

\section{RYCINA 3}

Symulacja zmian keratometrycznych rogówki przy zaplanowanym otwarciu komory przedniej oka o szerokości 3,2 mm w obszarze stromej osi krzywizny rogówki. Widok ekranu systemu wspomagania chirurga Verion.

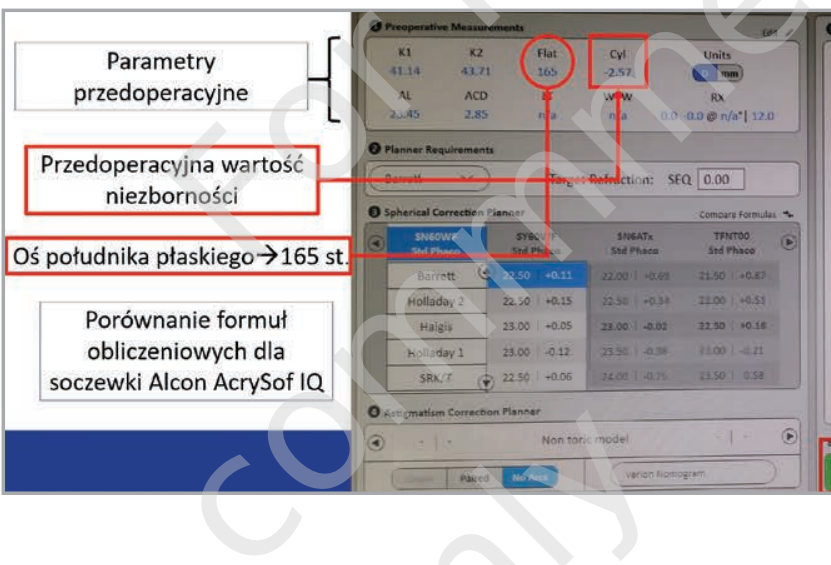

Z kolei w sytuacji, gdy gałka oczna wykazuje cechy astygmatyzmu wbrew regule, tzn. oś stromej krzywizny rogówki znajduje się $\mathrm{w}$ okolicy $180^{\circ}$, poszerzenie cięcia głównego wykonanego w południku na godzinie 12 (w obszarze południka płaskiego) dodatkowo zmniejszy krzywiznę rogówki w osi południka płaskiego i jednocześnie zwiększy krzywiznę w osi stromej.

Na rycinach 4 i 5 zobrazowano powyższą sytuację przy zastosowaniu systemu wspomagania chirurga Verion. U pacjenta $\mathrm{z}$ astygmatyzmem przedoperacyjnym o wartości 2,57 Dcyl, w osi stromej $165^{\circ}$ (oś płaskiego południka to $75^{\circ}$ ), w przypadku zaplanowanego otwarcia komory przedniej o szerokości $2,4 \mathrm{~mm}$ w osi $90^{\circ}$ astygmatyzm pooperacyjny będzie

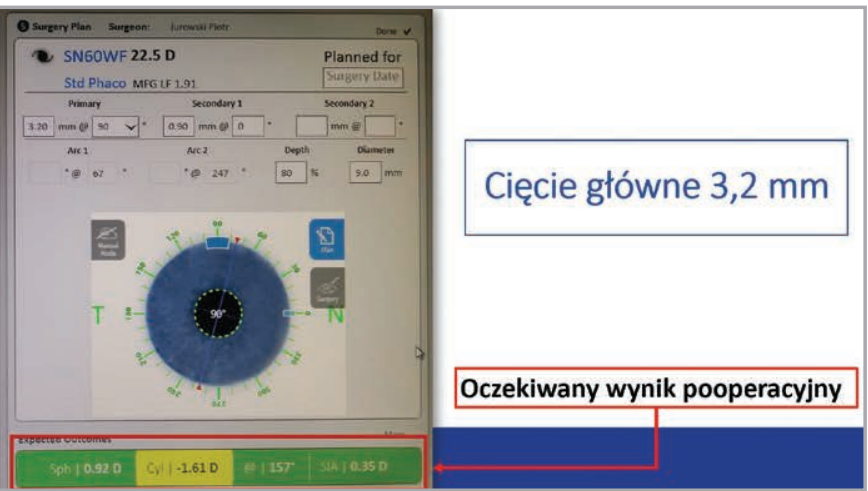

wynosił 2,93 Dcyl, a więc będzie większy od astygmatyzmu przedoperacyjnego o 0,36 Dcyl (ryc. 4). Przy poszerzeniu cięcia głównego do $3,2 \mathrm{~mm}$ astygmatyzm pooperacyjny będzie wynosił 3,16 Dcyl, czyli będzie większy od wartości sprzed operacji o 0,59 Dcyl (ryc. 5). 


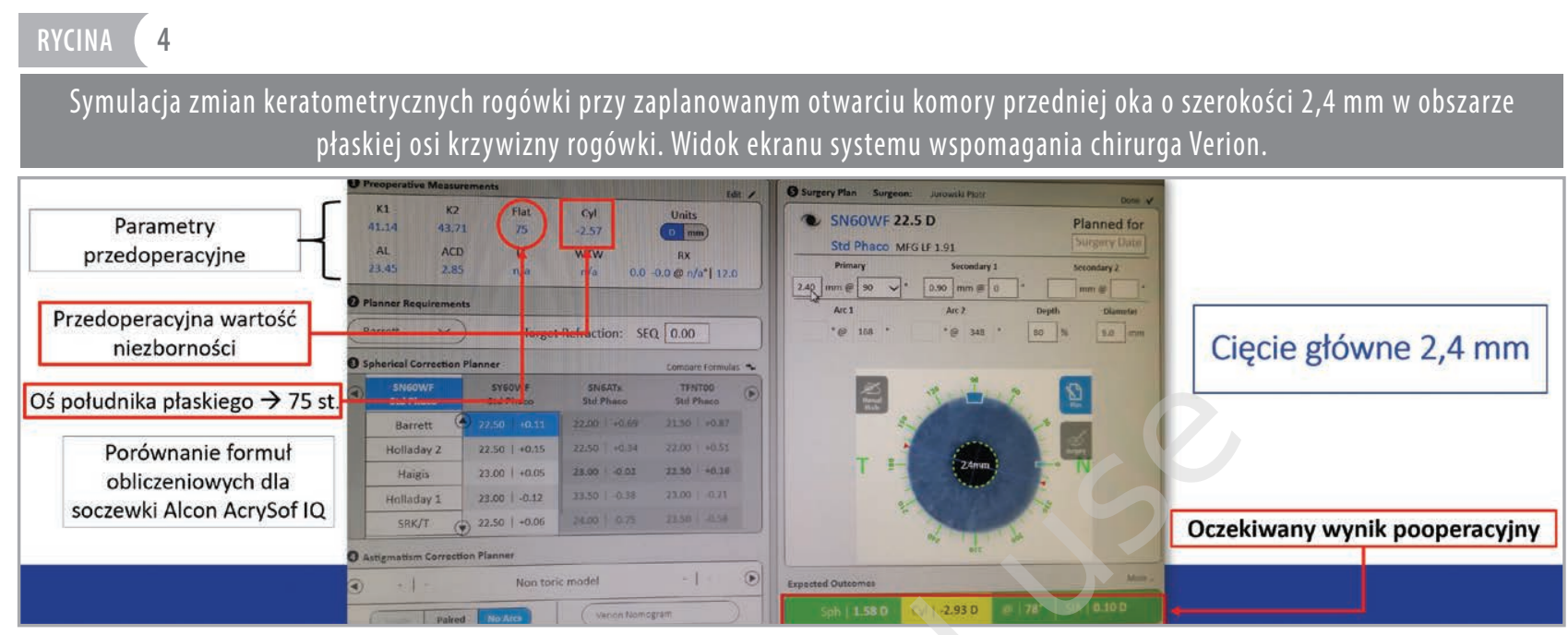

RYCINA $(5$

Symulacja zmian keratometrycznych rogówki przy zaplanowanym otwarciu komory przedniej oka o szerokości 3,2 mm w obszarze płaskiej osi krzywizny rogówki. Widok ekranu systemu wspomagania chirurga Verion.

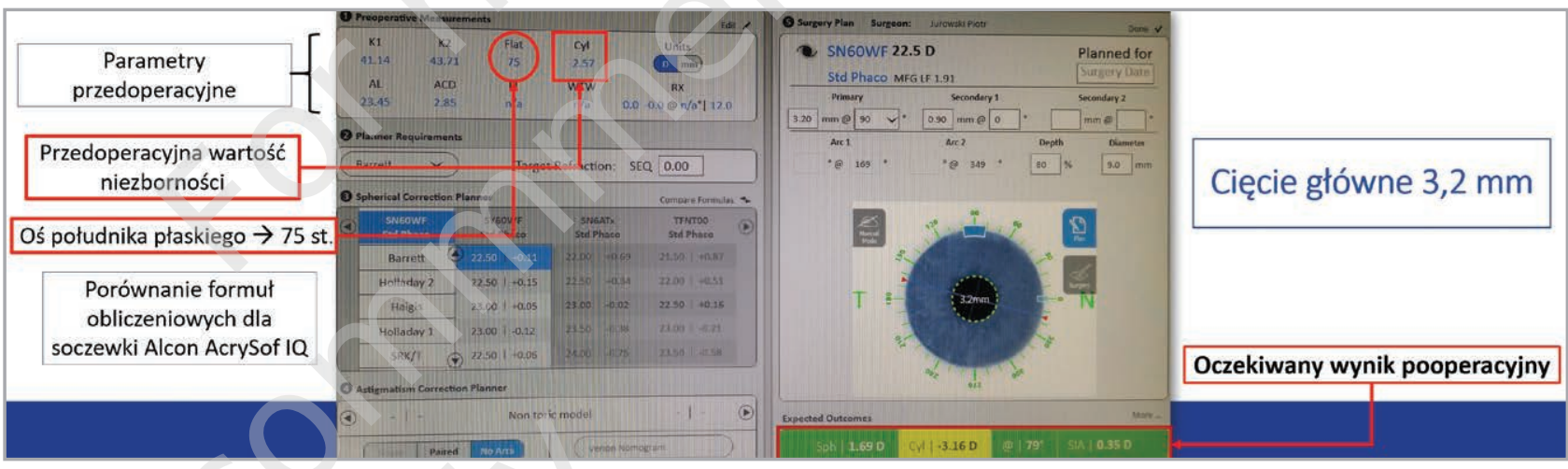

Istotne znaczenie dla wartości astygmatyzmu indukowanego chirurgicznie ma również wytworzenie dodatkowych otwarć komory przedniej. Taka konieczność może się pojawić w przypadku zmiany techniki operacyjnej z koaksjalnej na biaksjalną. Wprowadzenie do komory przedniej oka końcówek irygacyjno-aspiracyjnych wymaga wykonania jednego lub dwóch otwarć w rogówce o szerokości ok. 1,5 mm za pomocą noża typu sideport, noża 15-stopniowego lub noża MVR. Wnioski z przeprowadzonych dotychczas badań klinicznych porównujących astygmatyzm indukowany chirurgicznie w metodzie biaksjalnej i koaksjalnej wskazują, że ta pierwsza związana jest z mniejszą wartością SIA. Metaanalizy pokazują, że wspomniane techniki charakteryzują się podobnymi wynikami czynnościowymi i częstością powikłań. Technika biaksjalna generuje mniejszy astygmatyzm indukowany chirurgicznie, ale dłuższy jest czas fakoemulsyfikacji i częściej występuje pooperacyjny obrzęk rogówki. Z kolei w technice koaksjalnej obserwuje się krótszy sumaryczny czas operacji. Podkreśla się jednak, że refrakcja pooperacyjna w obu wspomnianych technikach jest podobna [7].

Badania własne oparte na pomiarach i analizie keratometrycznej wykonanej za pomocą systemu Verion prezentują odmienne wyniki. Przedstawiony na rycinach 6 i 7 przypadek dotyczy pacjenta $\mathrm{z}$ astygmatyzmem wbrew regule $\mathrm{z}$ osią stromą $180^{\circ} \mathrm{i}$ wartością astygmatyzmu przed operacją 0,99 Dcyl. Przy planowanej technice koaksjalnej z otwarciem komory przedniej o szerokości 2,4 mm w osi $90^{\circ}$, astygmatyzm pooperacyjny pacjenta wyniesie 1,57 Dcyl. W trakcie operacji wystąpiła konieczność konwersji z metody koaksjalnej do biaksjalnej z wytworzeniem dwóch $1,5 \mathrm{~mm}$ otwarć bocznych w osi $0^{\circ}$ i $180^{\circ}$. Badanie kontrolne po 2 tygodniach od operacji wykazało niezborność rogówkową 1,6 Dcyl, co stanowiło wartość bardzo zbliżoną do pierwotnie przewidywanej (ryc. 6). 4 tygodnie po operacji astygmatyzm rogówkowy wyno- 
sił 1,86 Dcyl i był o 0,26 Dcyl większy niż przewidywany (ryc. 7).

Można sądzić, że konieczność śródoperacyjnego wytworzenia dwóch bocznych otwarć komory przedniej w tej samej osi po przeciwległych stronach rogówki spowodowała zwiększenie wartości astygmatyzmu pooperacyjnego.

Inną przyczyną nieplanowanej pooperacyjnej ametropii jest zmiana miejsca fiksacji implantu soczewkowego. Konieczność wszczepienia sztucznej soczewki do bruzdy ciała rzęskowego, zamiast - jak planowano - do torebki soczew- ki, prowadzi do zmiany tzw. efektywnej pozycji soczewki. Jak wiadomo, zmiana ELP wiąże się również ze wzrostem efektywnej mocy refrakcyjnej sztucznej soczewki, co z kolei wymusza konieczność wybrania innego implantu, o mniejszej mocy refrakcyjnej, niż zaplanowany. W tabeli 3 przedstawiono informacje dotyczące korekty mocy sztucznej soczewki przy fiksacji w bruździe ciała rzęskowego w zależności od wartości mocy refrakcyjnej planowanego wszczepu do torebki soczewki.

\section{RYCINA 6 \\ Parametry keratometryczne po śródoperacyjnej konwersji z metody koaksjalnej do biaksjalnej - kontrolne badanie przeprowadzone 2 tygodnie po operacji. Widok ekranu systemu wspomagania chirurga Verion.}

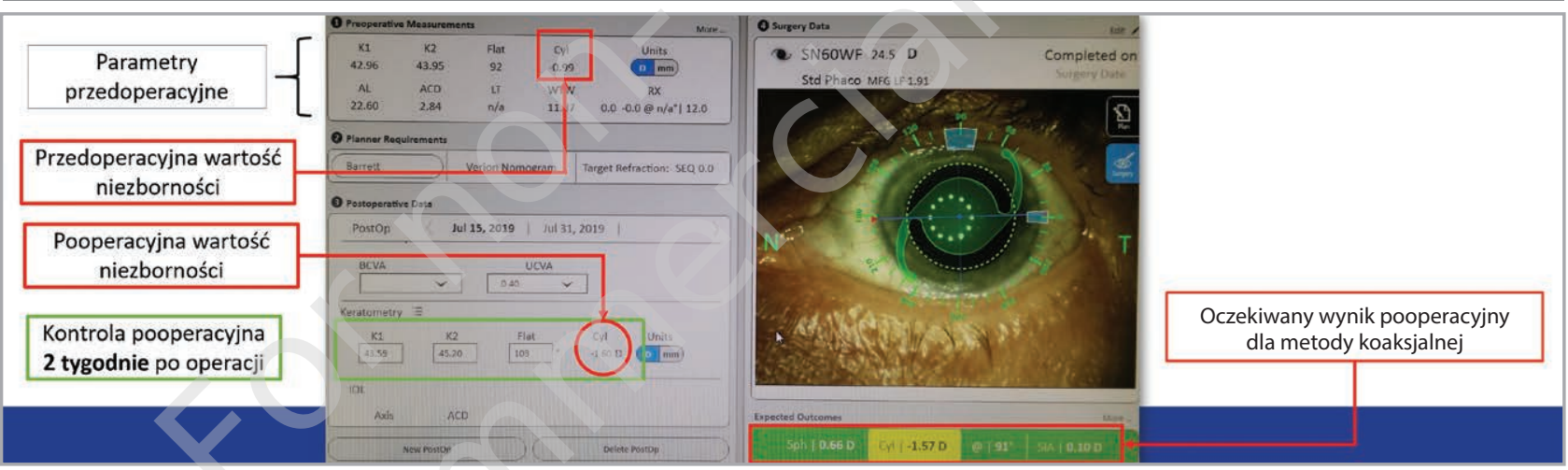

\section{RYCINA 7}

Parametry keratometryczne po śródoperacyjnej konwersji z metody koaksjalnej do biaksjalnej - kontrolne badanie przeprowadzone 4 tygodnie po operacji. Widok ekranu systemu wspomagania chirurga Verion.

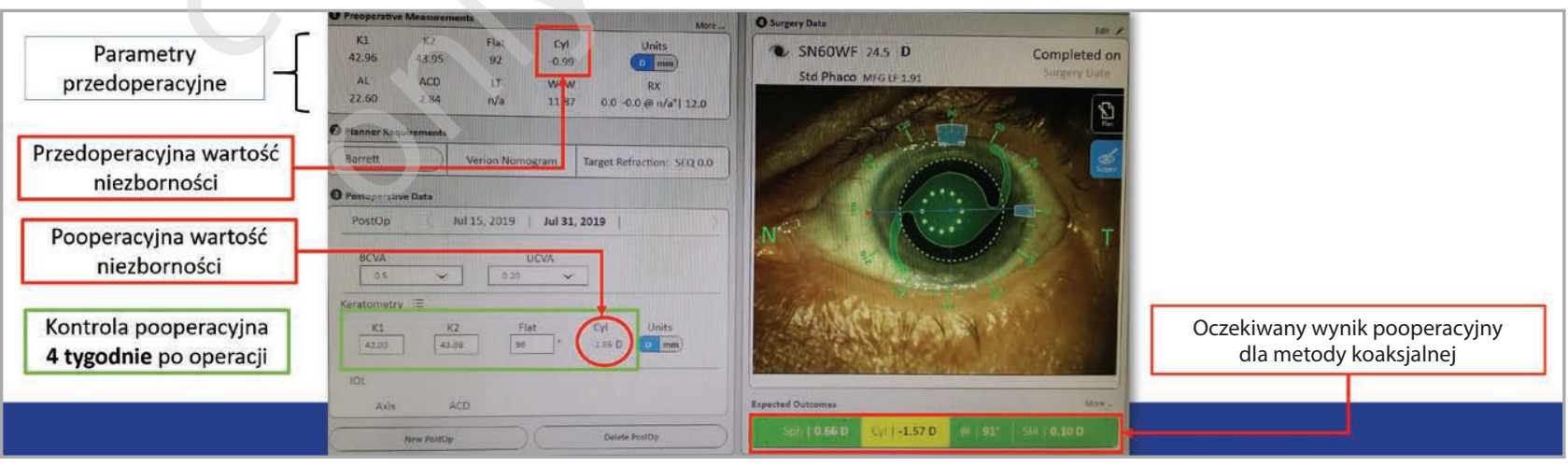

TABELA $(3$

Korekta mocy sztucznej soczewki wewnątrzgałkowej przy implantacji w bruździe ciała rzęskowego.

\begin{tabular}{c|c} 
Moc soczewki (wyliczona dla wszczepu do torby soczewki) & $\begin{array}{c}\text { Korekta mocy soczewki przy wszczepie do bruzdy ciała } \\
\text { rzęskowego }\end{array}$ \\
\hline od +30,0 Dsph do 25,5 Dsph & $-1,5$ Dsph \\
\hline od +25,0 Dsph do 15,5 Dsph & $-1,0$ Dsph \\
\hline od $+15,0$ Dsph do 8,5 Dsph & $-0,5$ Dsph \\
\hline od $+8,0$ Dsph do 1,0 Dsph & bez korekty
\end{tabular}




\section{PODSUMOWANIE}

Jednym z kluczowych elementów podczas planowania operacji fakoemulsyfikacji jest wyliczenie mocy refrakcyjnej wszczepu soczewkowego. Poza prawidłowo wykonanymi pomiarami morfometrycznymi gałki ocznej istotne jest również wybranie odpowiedniej formuły obliczeniowej i uwzględnienie historii okulistycznej pacjenta. Należy jednak mieć na uwadze, że mimo skrupulatnego wyliczenia mocy soczewki wewnątrzgałkowej, przy nawet niewielkich modyfikacjach techniki operacyjnej może wystąić pooperacyjna ametropia, co ma bezpośredni wpływ na jakość życia i zadowolenie pacjenta.

Źródto rycin: Wszystkie ryciny pochodza z materiałów własnych autora/autorów.

\section{ADRES DO KORESPONDENCJI}

\section{lek. Magdalena Skorek}

Klinika Okulistyki i Rehabilitacji Wzrokowej,

Uniwersytecki Szpital Kliniczny im. Wojskowej Akademii

Medycznej - Centralny Szpital Weteranów

90-549 Łódź, ul. Żeromskiego 113

e-mail: magdalena.skorek@outlook.com

\section{ORCID}

Magdalena Skorek - ID - http://orcid.org/0000-0003-4134-6270

Piotr Jurowski - ID - http://orcid.org/0000-0003-1471-8577

\section{Piśmiennictwo}

1. Gale RP, Saldana M, Johnston RL et al. Benchmark standards for refractive outcomes after NHS cataract surgery. Eye (Lond). 2009; 23(1): 149-52.

2. Hoffer KJ. The Hoffer Q formula: a comparison of theoretic and regression formulas. J Cataract Refract Surg. 1993; 19(6): 700-12.

3. Sanders DR, Retzlaff JA, Kraff MC et al. Comparison of the SRK/T formula and other theoretical and regression formulas. J Cataract Refract Surg. 1990; 16(3): 341-6.

4. Melles RB, Holladay JT, Chang WJ. Accuracy of Intraocular Lens Calculation Formulas. Ophthalmology. 2018; 125(2): 169-78.

5. Kane JX, Van Heerden A, Atik A et al. Intraocular lens power formula accuracy: Comparison of 7 formulas. J Cataract Refract Surg. 2016; 42(10): 1490-500.

6. Li PP, Huang YM, Cai Q et al. Effects of steep-axis incision on corneal curvature in one-handed phacoemulsification. Int J Ophthalmol. 2019; 12(8): 1277-82.

7. Chen C, Zhu M, Sun Y et al. Bimanual microincision versus standard coaxial small-incision cataract surgery: meta-analysis of randomized controlled trials. Eur J Ophthalmol. 2015; 25(2): 119-27.

Wkład autorów:

Magdalena Skorek: 75\%; Piotr Jurowski: 25\%.

Konflikt interesów:

Nie występuje.

Finansowanie:

Nie występuje.

Etyka:

Treści przedstawione w artykule są zgodne z zasadami Deklaracji Helsińskiej, dyrektywami EU oraz ujednoliconymi wymaganiami dla czasopism biomedycznych.
Authors' contributions:

Magdalena Skorek: 75\%; Piotr Jurowski: 25\%.

Conflict of interest:

None.

Financial support:

None.

Ethics:

The content presented in the article complies with the principles of the Helsinki Declaration, EU directives and harmonized requirements for biomedical journals. 